\title{
Lumbar Spinal Cord
}

National Cancer Institute

\section{Source}

National Cancer Institute. Lumbar Spinal Cord. NCI Thesaurus. Code C12895.

The portion of the spinal cord located in the lumbar region. 